\title{
Subcontinental lithospheric mantle beneath Central Europe
}

\author{
Jacek Puziewicz • Magdalena Matusiak-Małek • \\ Theodoros Ntaflos $•$ Michel Grégoire $•$ Anna Kukuła
}

Received: 30 December 2013 / Accepted: 19 December 2014 / Published online: 30 December 2014

(c) The Author(s) 2014. This article is published with open access at Springerlink.com

\begin{abstract}
Mantle xenoliths in Oligocene-Miocene alkaline lavas in Lower Silesia (SW Poland) and adjacent part of Upper Lusatia (SE Germany) are samples of the subcontinental lithospheric mantle at the time of culmination of rifting in the Eger Rift (Bohemian Massif, Central Europe). The xenoliths come from the spinel mantle facies and show that two major lithologies occur in the area: A-highly magnesian (olivine Fo 90.5-92.0) harzburgites, and Bless magnesian (olivine Fo 84.0-90.0) harzburgites. The protolith of group A was clinopyroxene-free harzburgite being the residue after extensive melting. It was affected by chromatographic carbonatite/silicate melt metasomatism, with the carbonatite metasomatism only recorded in distal parts of the chromatographic systems. The B harzburgites were penetratively metasomatised by percolating alkaline silicate melts at the time of volcanism. That metasomatism was mostly anhydrous and typically cryptic; it lowered the $\mathrm{Mg} /(\mathrm{Mg}+\mathrm{Fe})$ ratio of olivine and orthopyroxene in the peridotites subjected to melt percolation and led in places to dissolution of clinopyroxene. The mostly harzburgitic subcontinental mantle lithospheric domain beneath Lower Silesia and Upper Lusatia differs from the lherzolitic/
\end{abstract}

J. Puziewicz $(\triangle) \cdot$ M. Matusiak-Małek · A. Kukuła Institute of Geological Sciences, University of Wrocław, Pl. M. Borna 9, 50-204 Wrocław, Poland

e-mail: jacek.puziewicz@ing.uni.wroc.pl

T. Ntaflos

Department of Lithospheric Research, University of Vienna, Althanstrasse 4, 1090 Vienna, Austria

M. Grégoire

Geosciences Environment Toulouse, Midi-Pyrénées

Observatory, CNRS-IRD-Toulouse University, 14 av. E. Belin,

31400 Toulouse, France harzburgitic ones located to W and SW beneath other parts of European Variscan orogen.

Keywords Lithospheric mantle $\cdot$ Lithology · Metasomatism · Central Europe

\section{Introduction}

The subcontinental lithospheric mantle beneath Central and Western Europe was sampled by numerous volcanoes active since late Mesozoic until Quaternary. The area of volcanism stretches from Massif Central in France to Lower Silesia in Poland and is often termed as the "Central European Volcanic Province" (CEVP; Wimmenauer 1974). The CEVP is situated in the European Variscan orogen and marks its response to lithospheric stresses generated by the evolving Alpine orogen, which is located to the south (Dézes et al. 2004).

The alkaline lavas of CEVP have various compositions (Lustrino and Wilson 2007). The study of their chemical characteristics provides indirect information on thecommonly asthenospheric-source region. Many of those lavas contain lithospheric mantle xenoliths, which enable direct-sample based—study of lithospheric mantle at the time of volcanism. In this paper, we summarise our studies of mantle xenoliths occurring in the lavas of the eastern part of CEVP, comprising Lower Silesia (SW Poland) and adjacent part of Upper Lusatia (SE Germany). We show that lithospheric mantle peridotites have commonly been affected by melts migrating through the mantle at the time of volcanism and that in places harzburgites, being the residues of after extensive melting, are preserved, although mostly overprinted by carbonatite/silicate melt metasomatism. We also show that the harzburgitic subcontinental 
lithospheric mantle (SCLM) beneath Lower Silesia and Upper Lusatia is rather different from lherzolitic to harzburgitic SCLM beneath located more to the west and southwest part of the European Variscan orogen.

Mantle pyroxenites, which occur abundantly in one of the studied sites, have been shown to be the syn-volcanic cumulates of the alkaline lavas (Puziewicz et al. 2011) and are not included in this paper.

\section{Geological framework of the lithospheric mantle description}

Cenozoic alkaline volcanism in the Bohemian Massif is concentrated in the Eger (Ohře) Rift (Ulrych et al. 2011; Fig. 1). The Rift belongs to the European Cenozoic Rift System (ECRIS) formed in the Variscan foreland of the growing Alpine orogen (Dézes et al. 2004). The central part of the Eger Rift is manifested in the surface morphology as the Eger Graben (Ulrych et al. 2011). The Rift continues to NE beyond the Elbe Fault Zone to the Sudetic Marginal
Fault in SW Poland, although it is not visible in morphology (Badura and Aleksandrowski 2013). Here, the Rift is marked by numerous isolated lava occurrences, forming the Lubań-Frydlant volcanic "complex". Less numerous lava occurrences belonging to CEVP occur over $200 \mathrm{~km}$ to the SE of the northern Rift termination (Fig. 1) along the Labe-Odra fault system (Ulrych et al. 2011). They are concentrated in four volcanic "complexes": Złotoryja-Jawor, Niemcza-Strzelin, Lądek Zdrój and Niemodlin.

The main phases of volcanic activity in Eger Rift occurred in Oligocene and Lower Miocene times (Ulrych et al. 2011). Volcanic activity in Lower Silesia culminated in Eocene-Oligocene (34-26 Ma) and Lower Miocene (22-18 Ma); subordinate Pliocene-Pleistocene event took place at 5.5-1.0 Ma (K-Ar datings; Pécskay and Birkenmajer 2013; Birkenmajer and Pécskay 2002; Birkenmajer et al. 2002, 2004a, b, 2007, 2011).

We describe the lithology of subcontinental lithospheric mantle emerging from study of xenoliths from several localities (Fig. 1): Steinberg and Księginki, located at the margins of the NE termination of the Eger Rift, from

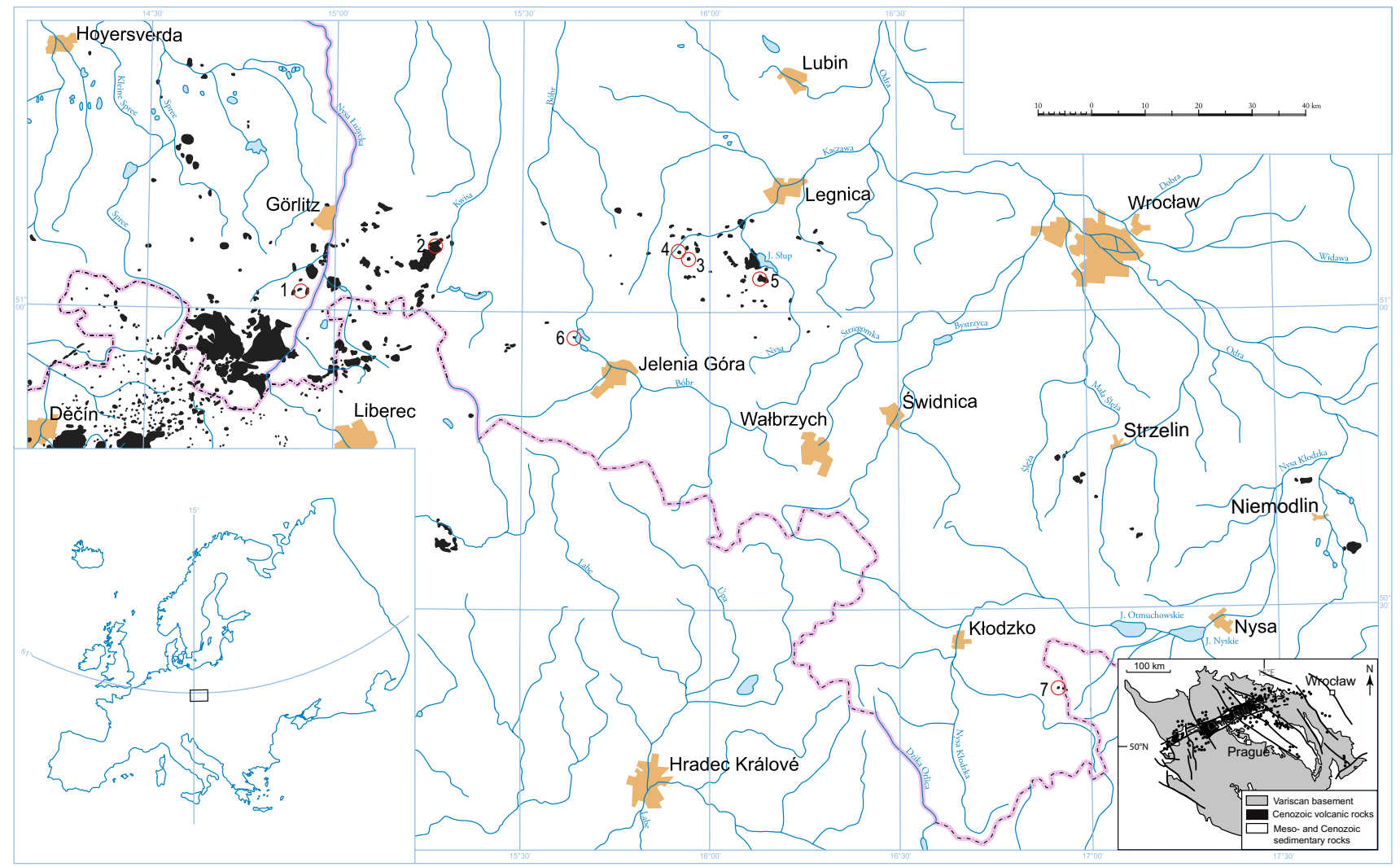

Fig. 1 Outcrops of Cenozoic alkaline volcanic rocks in SW Poland and neighbouring areas of Germany and Czech Republic (compiled by Michał Dajek and Danuta Lipa, University of Wrocław, on the basis of the "Geological map of Lower Silesia 1:100000" by Sawicki 1995). The inset in the right corner shows the location of the Eger
Rift relative to Variscan basement of the Bohemian Massif after Ulrych et al. (1999). Red circles mark the SCLM xenoliths occurrences described in this paper: 1 Steinberg, 2 Księginki, 3 Krzeniów, 4 Wilcza Góra, 5 Winna Góra, 6 Pilchowice, 7 Lutynia 
Krzeniów, Wilcza Góra and Winna Góra (the ZłotoryjaJawor Complex, off-rift location), and an isolated off-rift basalt occurrence in Pilchowice. The basanite from Steinberg is dated at ca. $30 \mathrm{Ma}$ (Tietz et al. 2013), whereas the nephelinite from Księginki is ca. 27-32 Ma (Birkenmajer et al. 2011). The Krzeniów basanite is ca. 19 Ma (Birkenmajer et al. 2007), the Wilcza Góra basanite is ca. $20 \mathrm{Ma}$ (Birkenmajer et al. 2007), and the Winna Góra basanite is ca. $22 \mathrm{Ma}$ (Birkenmajer et al. 2002). The nephelinite from Pilchowice is dated at $23 \mathrm{Ma}$ (Birkenmajer et al. 2011).

The xenoliths described were samples of the lithospheric mantle at the syn-rift culmination of volcanism in the Eger Rift, which occurred from 32 to $18 \mathrm{Ma}$ (Ulrych et al. 2011). A study of Ksieginki xenoliths showed that the lithospheric mantle was heated at this time (ca. $30 \mathrm{Ma}$ ) by lavas moving upwards both in channelised and pervasive modes (Puziewicz et al. 2011). Therefore, our data describe the hot syn-rift state of the lithospheric mantle. The much younger xenolith suites from Kozákov in Czech Republic (ca. 4.0 Ma, Šibrava and Havlíček 1980; Ackerman et al. 2007) and Lutynia (5.5-3.8 Ma, Birkenmajer et al. 2002; Matusiak-Małek et al. 2010) represent the cooled mantle lithologies, and conductive geotherms have been proposed for both sites (Christensen et al. 2001; Puziewicz et al. 2012).

\section{Analytical methods and terminology}

The data presented in this paper come from published (Puziewicz et al. 2011; Ćwiek et al. 2013; Kukuła et al. 2013; Matusiak-Małek et al. 2014) and unpublished studies. Modal composition of peridotites from Księginki and Krzeniów was estimated by using digital method of image analysis by Higgins (2000) and that of peridotites from other localities by JMicroVision software on high-resolution scans of one thick section per xenolith. The modal analyses of the xenoliths from the sites described in our study were previously presented by many authors (e.g. Kozłowska-Koch 1981; Smulikowski and Kozłowska-Koch 1984), but we use only the data from xenoliths studied by us in the following section.

The chemical composition of minerals was analysed by using the CAMECA SX100 electron microprobe at the Department of Lithospheric Research, University of Vienna (for details see Puziewicz et al. 2011). Trace element contents in minerals were analysed by LA-ICP-MS technique at Géosciences Environnement Toulouse, Observatoire Midi Pyrénées, University Toulouse III, Toulouse (for details see Puziewicz et al. 2011) and at Polish Academy of Sciences in Kraków (for details see Matusiak-Małek et al. 2014). Since this paper is intended to show broad spectrum of data, we present them in figures; the analytical data

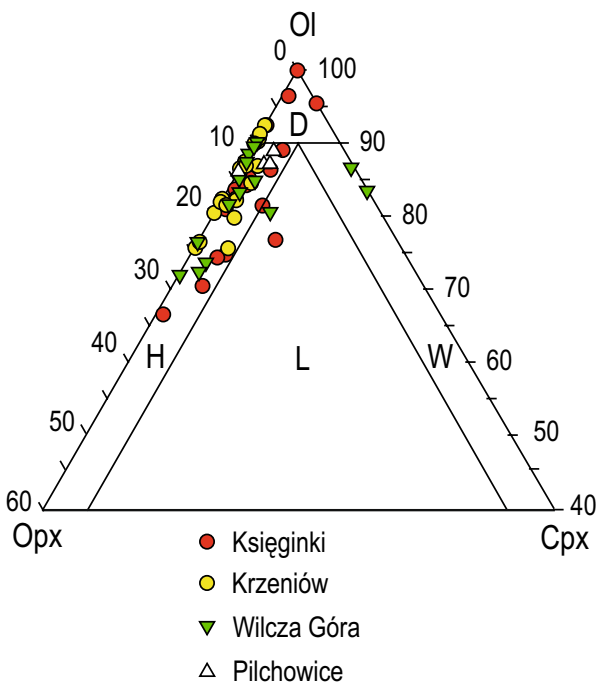

Fig. 2 Modal composition of xenoliths from Księginki, Krzeniów, Wilcza Góra and Pilchowice in the ol-cpx-opx IUGS classification diagram. $D$ dunites, $H$ harzburgites, $L$ lherzolites and $W$ wehrlites

presented in the figures are available in the papers describing individual sites or from the first author upon request.

We use the IUGS terminology for rocks and that of Morimoto (1989) for pyroxenes. The formulae of silicates are calculated assuming total $\mathrm{Fe}$ as $\mathrm{Fe}^{2+}$, whereas the content of $\mathrm{Fe}^{3+}$ in spinel is calculated by charge balance. The atomic ratio of $\mathrm{Mg} /\left(\mathrm{Mg}+\mathrm{Fe}^{2+}\right)$ in formula units of orthoand clinopyroxene and spinel is denoted as $\mathrm{mg \#}$ that of $\mathrm{Cr} /(\mathrm{Cr}+\mathrm{Al})$ in formula units of spinel as cr\#. The "Fo" denotes molar \% of forsterite in olivine, and the "apfu" stands for "atom/atoms per formula unit".

\section{Lithology of the syn-rift lithospheric mantle beneath Lower Silesia}

The xenoliths derived from the lithospheric mantle beneath the SW Poland are of spinel-peridotite mantle facies. Their modes are predominantly harzburgitic (Fig. 2). Lherzolites are very rare. Olivine and orthopyroxene are the primary minerals (Fig. 3a). Clinopyroxene is often absent or occurs only in volumetrically minor amounts. Its grains are typically smaller than those of orthopyroxene and olivine and are situated interstitially (Fig. 3b). Spinel either occurs in small amounts or is absent. In most localities, the mantle lithologies are anhydrous. The exception is Wilcza Góra, where most xenoliths contain small amounts $(\leq 1.6 \mathrm{vol} \%)$ of amphibole. The occurrence of amphibole was also noted from Wołek Hill in the Złotoryja-Jawor Complex (Napieralska and Muszyński 2006).

Primary olivine contains typically $84-92 \mathrm{~mol} \%$ of forsterite (Fig. 4). The content of forsterite in primary olivine 


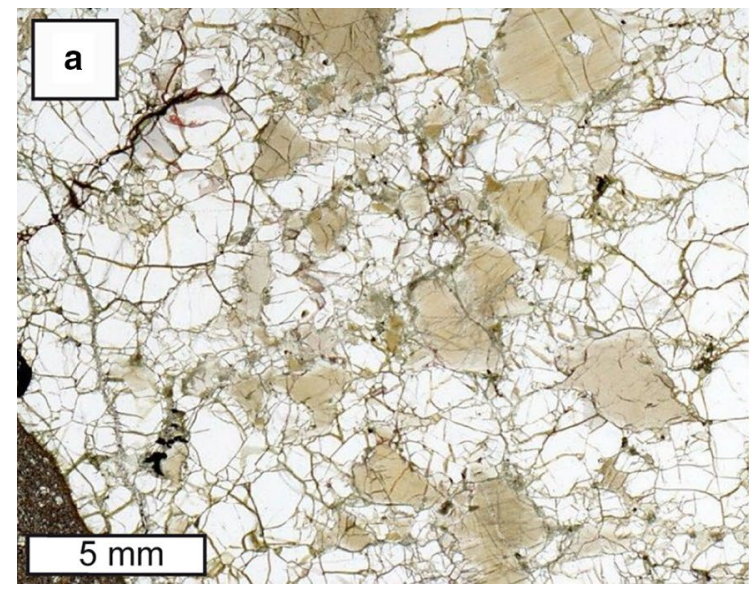

Fig. 3 Representative examples of peridotite textures. a Typical harzburgite of "A" lithology, olivine is white, orthopyroxene brownishgrey (sample MM44 from Krzeniów, olivine 82.2, orthopyroxene 16.0 , clinopyroxene 1.6 , spinel $0.2 \mathrm{vol} \%$ ); optical image, plane polar-

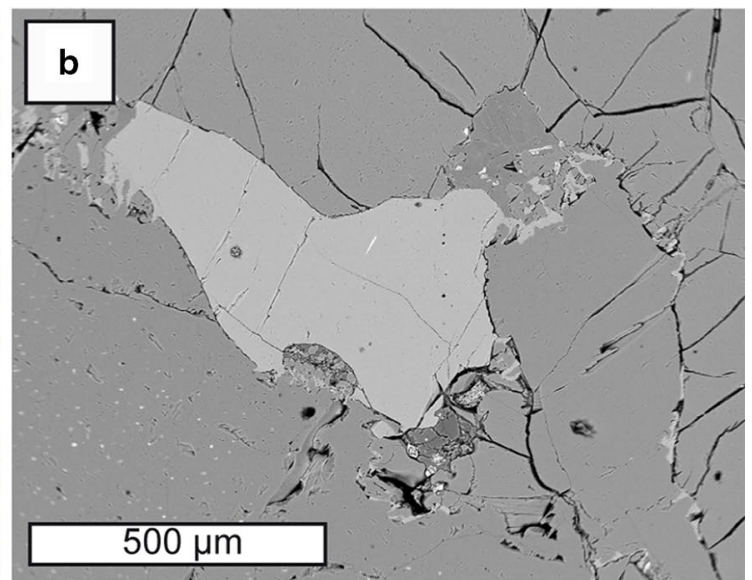

ised light; $\mathbf{b}$ interstitial clinopyroxene among the grains of olivine and orthopyroxene in the "A" harzburgite (sample MM45 from Krzeniów, olivine 73.4, orthopyroxene 19.8, clinopyroxene 3.9, spinel 2.9 vol\%); BSE image
Fig. 4 Relationship between forsterite $(\mathrm{mol} \%)$ and $\mathrm{NiO}$ $(\mathrm{wt} \%)$ content in olivine from mantle xenoliths from SW Poland. Various samples are depicted by identical symbols in this figure and in Figs. 5 and 6 to allow comparison
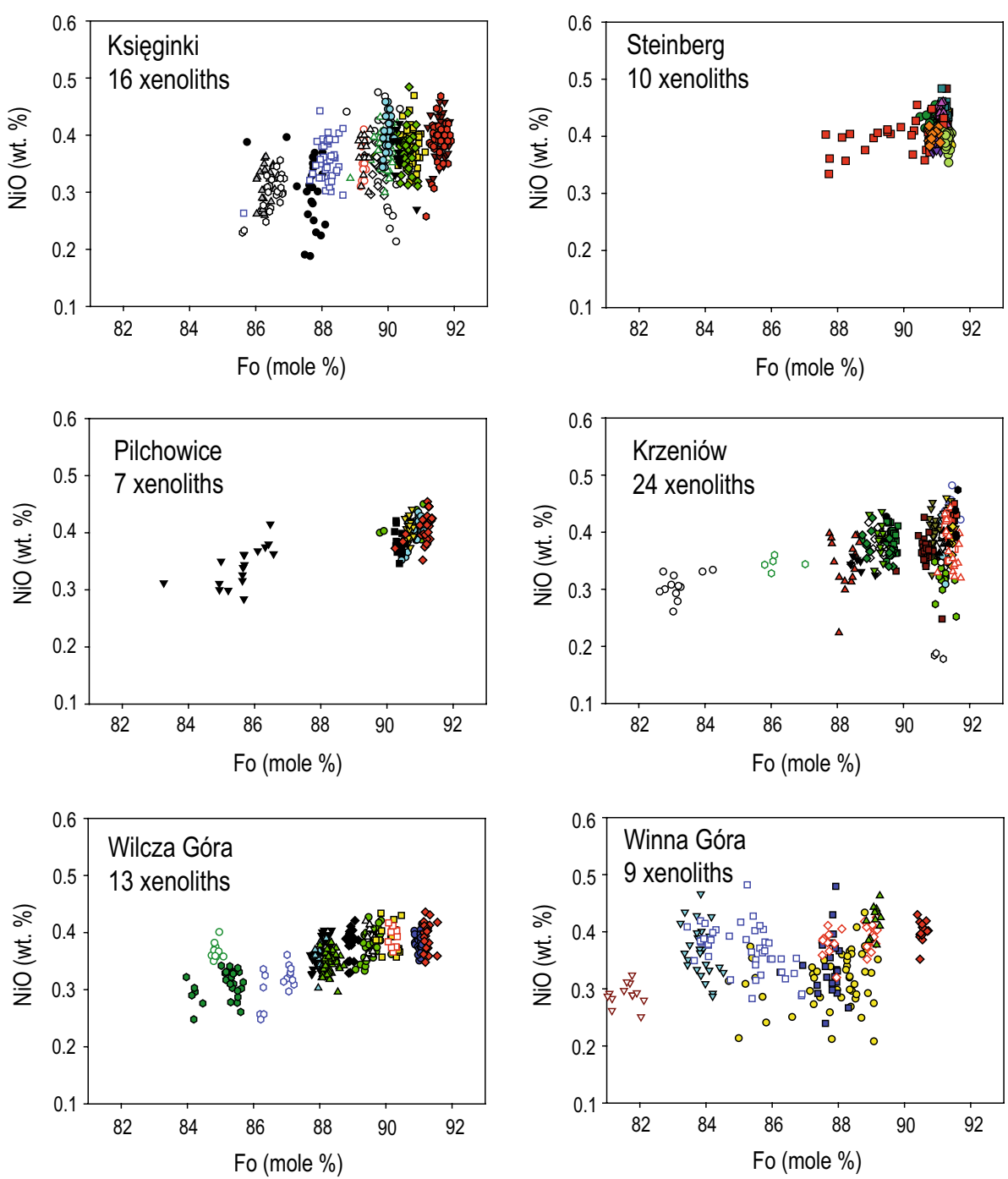

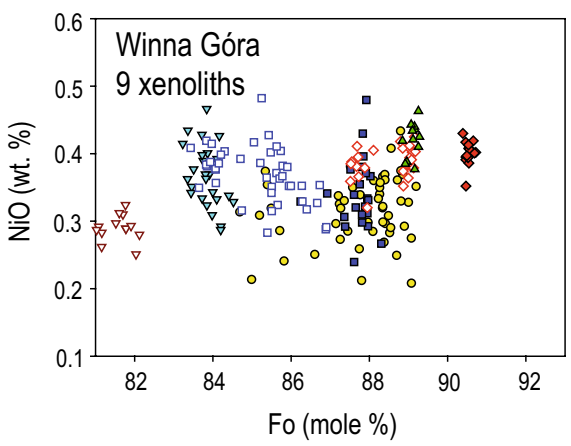


Fig. 5 Relationships between $\mathrm{Al}$ content (atoms per formula unit) and $\mathrm{mg \#} \mathrm{(atomic} \mathrm{Mg}$ / $(\mathrm{Mg}+\mathrm{Fe})$ in formula unit) in orthopyroxenes from mantle xenoliths from SW Poland. Various samples are depicted by identical symbols in this figure and in Figs. 4 and 6 to allow comparison
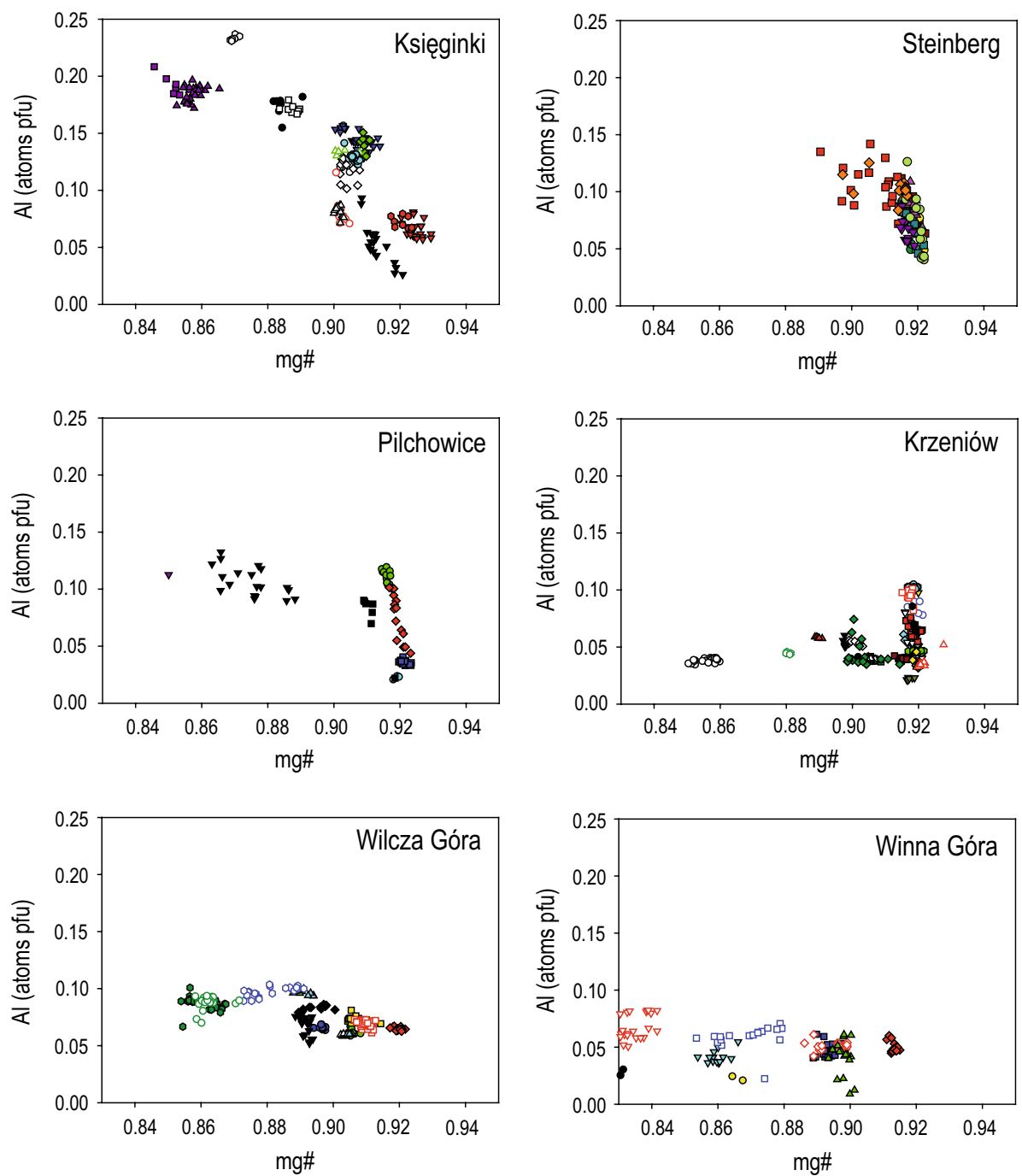

classifies the xenoliths into two groups: (1) highly magnesian group A and (2) moderately magnesian group B (Matusiak-Małek et al. 2014). Olivine in group A peridotites contains approximately $90.5-92.0 \%$ Fo, whereas that in group B contains approximately $84.0-90.0 \%$ Fo.

The highly magnesian A peridotites contain orthopyroxene which has mg\# similar to that of coexisting olivine and which is poor in $\mathrm{Al}$ (typically $<0.10$ atoms of $\mathrm{Al}$ pfu; Fig. 5). The orthopyroxene occurring in the B peridotites exhibits variable $\mathrm{mg \#}$ and low, approximately constant $\mathrm{Al}$ content (Fig. 5). The exception is the peridotites from Księginki, in which orthopyroxene shows well-defined negative correlation between mg\# and $\mathrm{Al}$ content (Fig. 5). Clinopyroxene in group A peridotites is usually strongly magnesian (mg\# 0.92-0.95), poor in $\mathrm{Al}$ (Fig. 6) and rich in $\mathrm{Ca}$, which typically exceeds 0.9 apfu. It shows some variation in $\mathrm{Al}$ and $\mathrm{Ca}$ contents, the most magnesian compositions being most impoverished in $\mathrm{Al}$ and most enriched in $\mathrm{Ca}$ (Fig. 7). Clinopyroxene in group $\mathrm{B}$ xenoliths is characterised by lower mg\# (cf. Fig. 6) and low Al content $(<0.10 \mathrm{apfu})$ in Krzeniów or by Al content negatively correlated with mg\# in Księginki. Group B clinopyroxene is also less calcic than that of group A (Fig. 7).

The xenoliths are usually too small $(<5 \mathrm{~cm})$ to allow representative bulk rock chemical analyses. Since clinopyroxene is the main repository of trace elements in spinel facies mantle peridotites, trace element compositions were studied in situ in clinopyroxene. Trace element contents in group A clinopyroxene are usually lower than or close to that of primitive mantle, except for the LREE, which are enriched in some localities. Their REE patterns vary between "spoon-shaped" and asymmetric "U-shaped" (Fig. 7). The group A trace element patterns exhibit deep $\mathrm{Nb}-\mathrm{Ta}$ and $\mathrm{Zr}-\mathrm{Hf}$ negative anomalies (Fig. 7). Ti is always depleted relative to primitive mantle (Fig. 7). Elevated Th-U contents occur locally.

Group B clinopyroxene is richer in trace elements, with concentrations are above those of primitive mantle. Its patterns typically show an increase from HREE to LREE with 
Fig. 6 Relationships between $\mathrm{Al}$ content (atoms per formula unit) and $\mathrm{mg}$ number (atomic $\mathrm{Mg} /(\mathrm{Mg}+\mathrm{Fe})$ in formula unit) in clinopyroxenes from mantle xenoliths from SW Poland. Various samples are depicted by identical symbols in this figure and in Figs. 4 and 5 to allow comparison
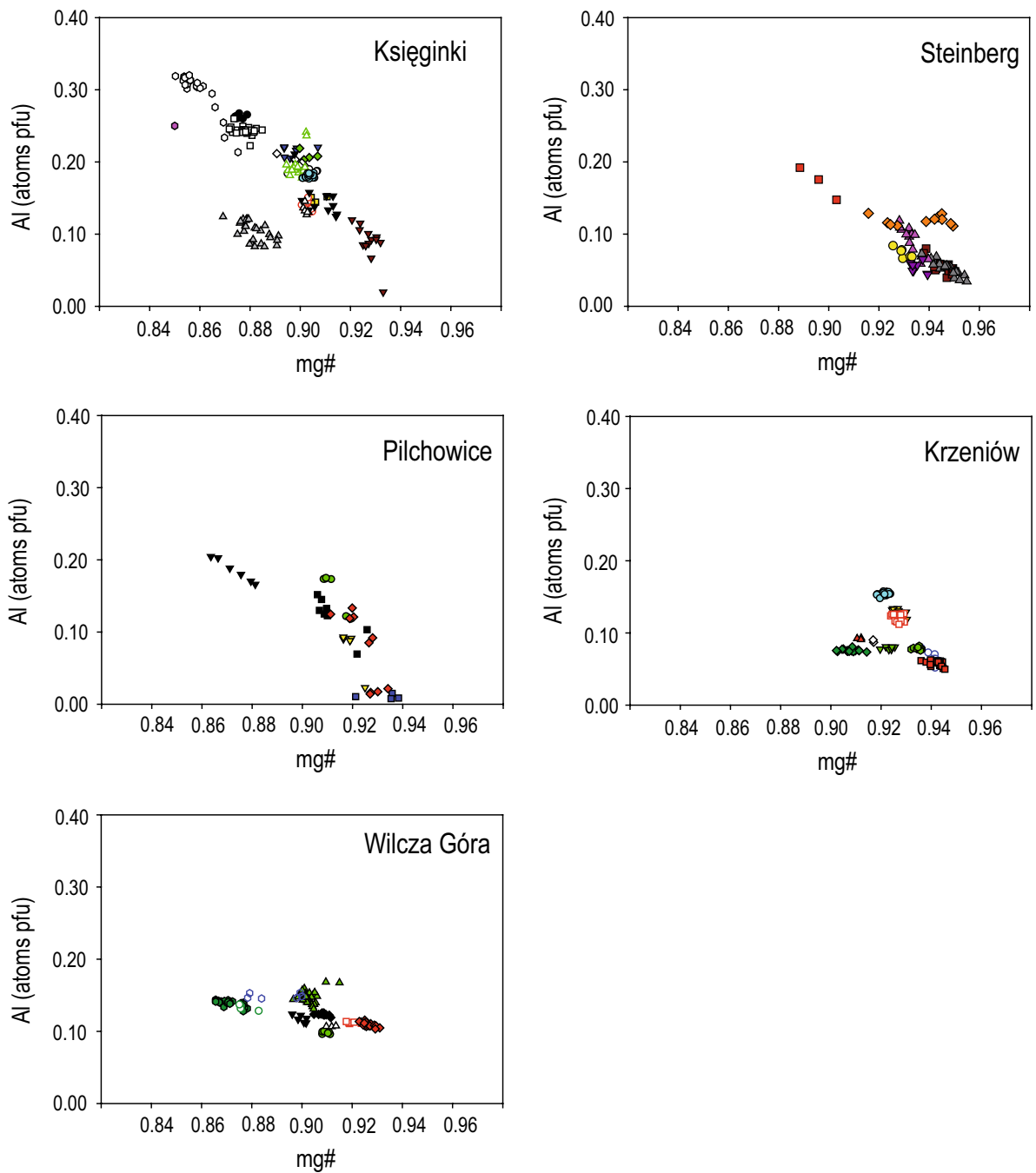

an inflection in LREE (Fig. 7). The trace element patterns show anomalies similar to those of "A" clinopyroxene, but generally much shallower except for Ti in some (Fig. 7).

Spinel is typically sparse and is commonly associated with fine-grained aggregates representing infiltrated silicate melt (Matusiak-Małek et al. 2013). We suspect that spinels in this kind of aggregates have been chemically affected by the melt (e.g. Krzeniów), and thus, we do not discuss them. Spinel that surrounds primary phases is characterised by high and variable cr\# (e.g. 0.40-0.54 in Steinberg) which suggests that its chemical composition is not equilibrated.

\section{Pliocene samples of off-rift lithospheric mantle from Lutynia}

The basanite lava from Lutynia and Zálesí dated at ca. 3.85.7 Ma (Birkenmajer et al. 2002; Ulrych et al. 2013) also contains harzburgite and clinopyroxene-poor lherzolite xenoliths (Fig. 8; for detailed description see MatusiakMałek et al. 2010) occurring in the off-rift setting (Fig. 1) and sampled ca. $13 \mathrm{Ma}$ after the culmination of syn-rift volcanism. The rocks are mostly protogranular and contain spinel-clinopyroxene symplectites. Olivine is characterised by high Fo content (89.9-92.4 mol\%) classifying them within the A lithology. Orthopyroxene has high mg\# (0.90-0.92) and variable Al content ( $<0.18$ apfu, Fig. 8). Clinopyroxene is also highly magnesian (0.91-0.95), and its mg\# is negatively correlated with $\mathrm{Al}$ (Fig. 8) and positively with $\mathrm{Ca}$ (0.91-0.95 apfu). Spinel mg\# varies from 0.68 to 0.80 , cr\# from 0.17 to 0.35 , rarely reaching 0.48 . Amphibole lamellae in clino- and orthopyroxene occur in one harzburgite. The REE and trace element patterns of clinopyroxene (Fig. 8) are similar to those typical for A group, although patterns similar to those of group B are also present. 

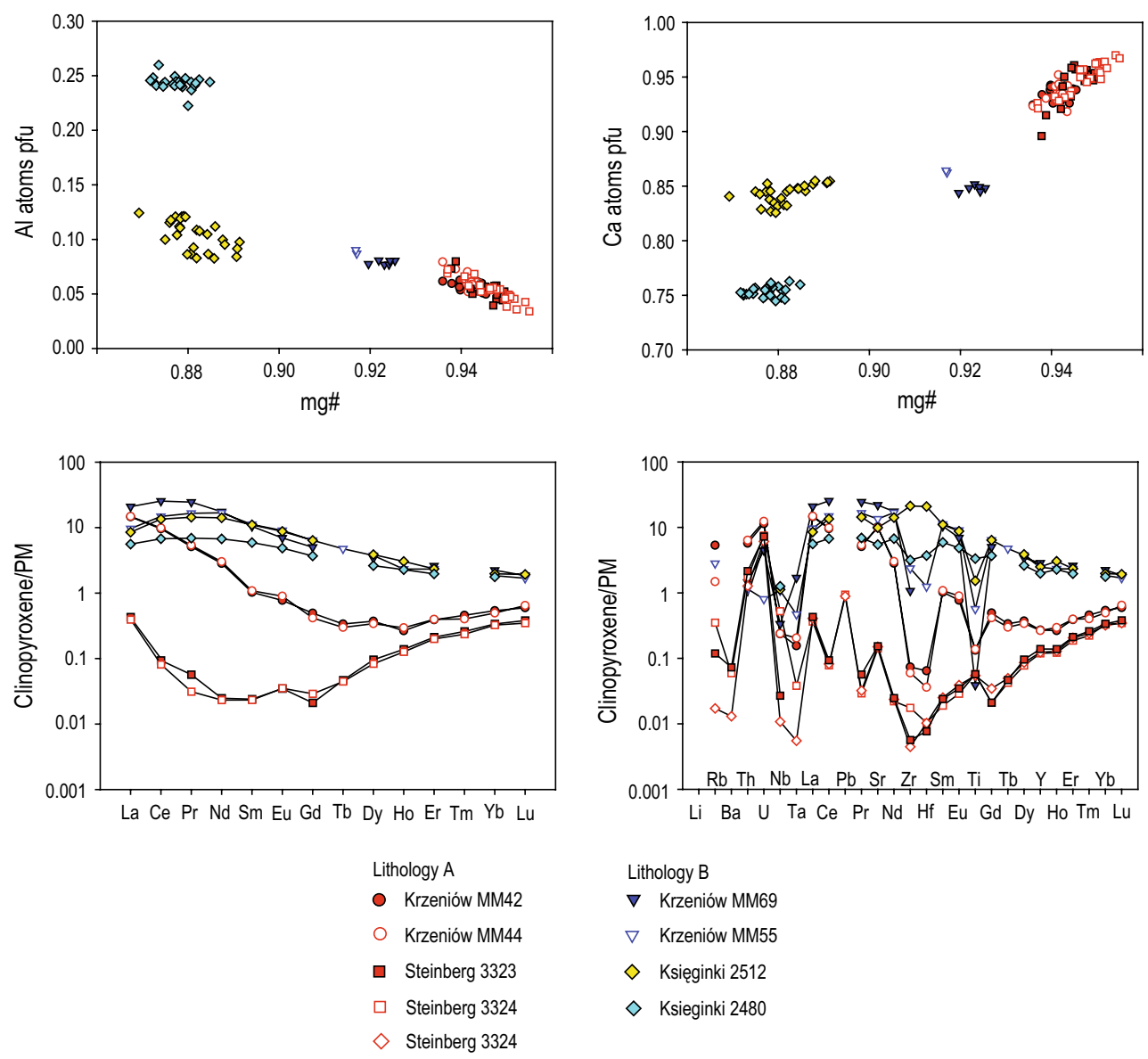

Fig. 7 Representative chemical data of clinopyroxene occurring in the " $\mathrm{A}$ " and "B" lithologies: $\mathrm{mg \#}$ versus $\mathrm{Al}$ and $\mathrm{Ca}$ contents (in atoms per formula unit) and primitive mantle (McDonough and Sun 1995)

normalised REE and trace element patterns. All samples are harzburgites except Księginki 2512 which is dunite

\section{Discussion}

Geological controls of the subcontinental lithospheric mantle lithology

The Bohemian Massif was assembled during Variscan times, and the seismic anisotropy of its lithospheric mantle differs among major tectonic units (Plomerová et al. 2012 and references therein). The lithospheric mantle of Lower Silesia and adjoining part of Upper Lusatia exhibits "Saxothuringian" seismic characteristics (Plomerová et al. 2012), suggesting that it is a coherent fragment of mantle root of one of the terranes accreted to the Variscan orogen. Geological models of the evolution of the Variscan orogen assume significant post-orogenic delamination and upwelling of asthenospheric material (Ziegler and Dèzes 2005; Massone 2006). Therefore, at the end of Variscan time, the subcontinental lithospheric mantle (SCLM) of the peneplained orogen probably consisted of mantle roots of the accreted terranes, which in places have been replaced by lithospherised

upwelled asthenosphere. This lithospheric mantle was further modified during the Alpine orogeny by migrating alkaline silicate melts (Puziewicz et al. 2011) and possibly by other metasomatic media.

The Moho in this area is located at depths of $30-35 \mathrm{~km}$ (e.g. Majdanski et al. 2006; Grad et al. 2008; Geissler et al. 2012). Data from Puziewicz et al. (2011) show that, at the time of rifting, the temperature of advectively heated lithospheric mantle was probably close to $1,100{ }^{\circ} \mathrm{C}$ at depths slightly beneath the Moho. Above $1,100{ }^{\circ} \mathrm{C}$, the stability field of spinel lherzolites expands significantly to pressures exceeding 1.7 GPa (Walter et al. 2002 and references therein), which corresponds to ca. $56 \mathrm{~km}$ depth. The transition from spinel to garnet facies in "hot" lithospheric mantle takes place between 50 and $70 \mathrm{~km}$ depth (Ziberna et al. 2013). Since the mantle peridotite xenoliths in the alkaline lavas of Central Europe belong to the spinel facies, we suggest that (1) the spinel- to garnet-facies transition corresponded to the rheological boundary between lithosphere and asthenosphere at the time of volcanism and (2) $70 \mathrm{~km}$ 
Fig. 8 3.8-5.7 Ma Lutynia lithospheric mantle xenoliths. The data based on 15 samples studied in detail by Matusiak-Małek et al. (2010). Various samples are depicted by identical symbols in all diagrams. a Points representing modal composition of xenoliths in the IUGS classification diagram. $D$ Dunites, $H$ harzburgites, $L$ lherzolites and $W$ wehrlites; b relationships between forsterite $(\mathrm{mol} \%)$ and $\mathrm{NiO}(\mathrm{wt} \%)$ content in olivine; c relationships between $\mathrm{Al}$ content (atoms per formula unit) and $\mathrm{mg \#}$ (atomic $\mathrm{Mg} /(\mathrm{Mg}+\mathrm{Fe}$ ) in formula unit) in orthopyroxene; $\mathbf{d}$ relationships between $\mathrm{Al}$ content (atoms per formula unit) and $\mathrm{mg}$ number (atomic $\mathrm{Mg} /(\mathrm{Mg}+\mathrm{Fe})$ in formula unit) in clinopyroxene; e primitive mantle (McDonough and Sun 1995) normalised REE patterns; f primitive mantle (McDonough and Sun 1995) normalised trace element patterns
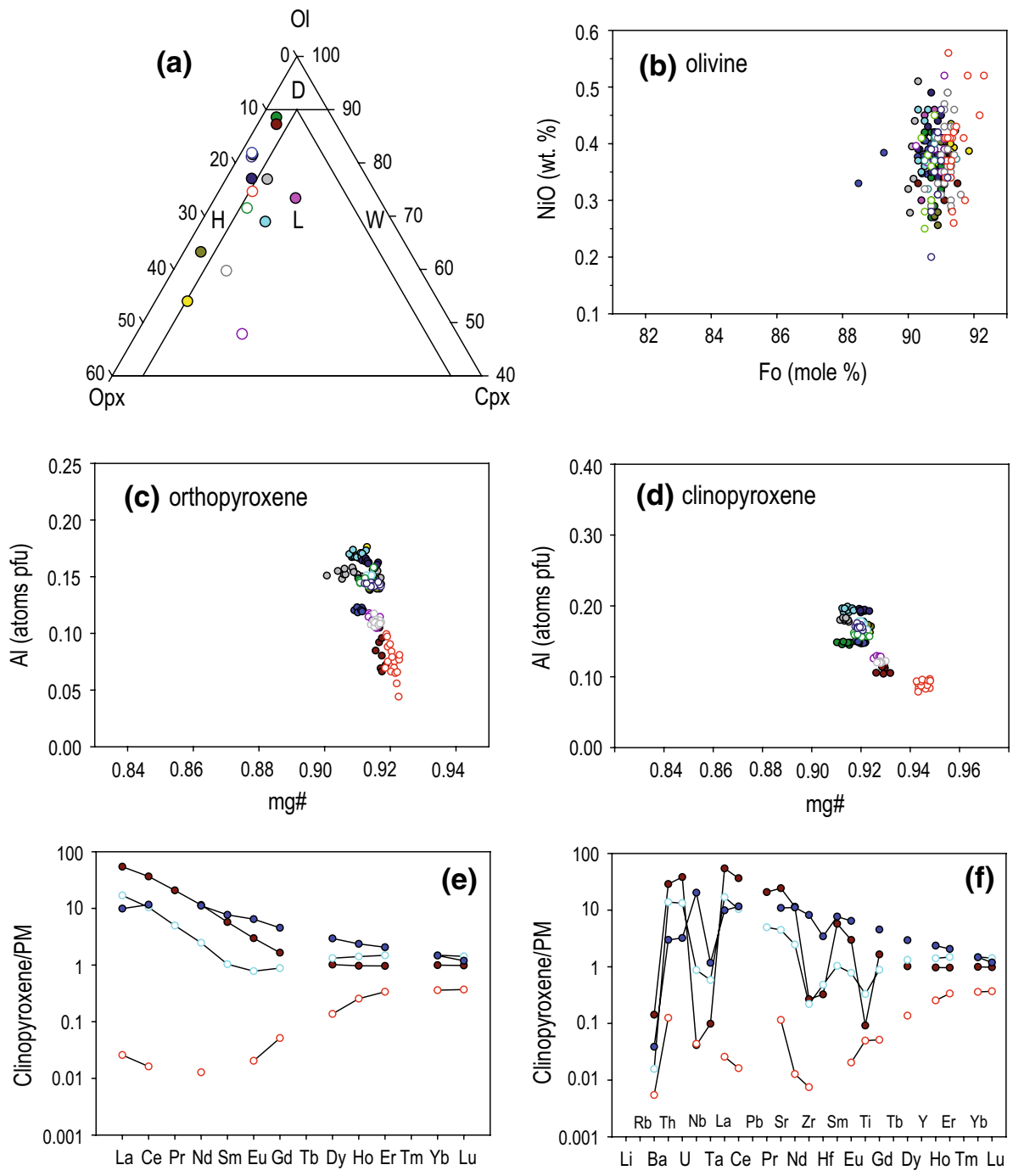

is the maximum depth of the lithosphere-asthenosphere boundary at the time of the syn-rift culmination of volcanism in this part of the Bohemian Massif. Thus, the mantle samples described here come most probably from the mantle section located at depths from 30 to $70 \mathrm{~km}$.

\section{Thermal evolution of the SCLM}

To estimate the thermal state of the studied SCLM, we have used two geothermometers: (1) based on ortho- and clinopyroxene solvus (Brey and Köhler 1990) and (2) based on equilibrium between orthopyroxene and spinel (Witt-Eickschen and Seck 1991). In numerous samples, the ortho- and clinopyroxene or orthopyroxene and spinel are not in equilibrium, which makes the estimations of temperatures impossible [disequilibrium results in calculated temperatures spanning up to $80{ }^{\circ} \mathrm{C}$ in a single xenolith (Brey and Köhler 1990 algorithm) or up to $130{ }^{\circ} \mathrm{C}$ (WittEickschen and Seck 1991 algorithm)]. Brey and Köhler's
(1990) algorithm yields consistent results in xenoliths from Księginki and Wilcza Góra, and some samples from Krzeniów and Lutynia. The "Al-Cr in orthopyroxene" geothermometer (Witt-Eickschen and Seck, 1991) gives temperatures similar to or slightly higher than those estimated with the use of Brey and Köhler (1990) algorithm.

The distribution of temperatures in the lithospheric mantle during syn-rift volcanism was in our opinion shaped by advective heat input from the magmas moving from their asthenospheric sources to the surface. The volume of moving magmas and/or the time of their migration was sufficient to rise temperature of SCLM beneath Księginki (on-rift location) to temperatures $1,060-1,120{ }^{\circ} \mathrm{C}$ at depth $35-50 \mathrm{~km}$ (Puziewicz et al. 2011). The data from off-rift sites generally show temperatures varying between 910 and $1,000{ }^{\circ} \mathrm{C}$ (Wilcza Góra and some xenoliths from Krzeniów, Pilchowice, Winna Góra, irrespective of their chemical classification into A or B group), suggesting that temperatures increased during rifting, but were variable at the local 
scale. Slightly lower temperatures are recorded only in some group B xenoliths from Winna Góra and Krzeniów (870-930 $\left.{ }^{\circ} \mathrm{C}\right)$. Some Krzeniów group A xenoliths containing clinopyroxene with elevated mg\# record temperatures of $830-865{ }^{\circ} \mathrm{C}$. Precise estimates of pressure in the studied samples are not possible, so the geothermometric data show the temperature distribution at depths between 30 and $70 \mathrm{~km}$. They suggest that the SCLM in the off-rift locations was $100-200{ }^{\circ} \mathrm{C}$ colder comparing to that in the onrift Księginki site (max. $\left.1,120^{\circ} \mathrm{C}\right)$, and that the depleted $\mathrm{A}$ peridotites possibly record lower temperatures from a time preceding the SCLM heating during Alpine syn-rift culmination of the volcanism.

Temperatures of $960-1,000{ }^{\circ} \mathrm{C}$ are reported for the younger Lutynia xenoliths (Matusiak-Małek et al. 2010), for which Puziewicz et al. (2012) speculated the $50 \mathrm{~km}$ depth of origin. These temperatures are similar to those characterising the off-rift SCLM at the time of syn-rift volcanism culmination. This suggests that post-rift cooling of the SCLM in the Lower Silesia was relatively slow. We suggest that the possible explanation is heating due to the prolonged magma production in the asthenospheric mantle, manifested by the post-rift episodes of volcanism (16$0.26 \mathrm{Ma}$, Ulrych et al. 2011).

The origin of "A" SCLM lithology beneath Lower Silesia and Upper Lusatia

The clinopyroxene in " $\mathrm{A}$ " harzburgites is texturally interstitial and later than the olivine and orthopyroxene. It is $\mathrm{Ca}$-rich, $\mathrm{Al}$-poor and strongly magnesian. High $\mathrm{Ca}$ content and high $\mathrm{mg \#}$ suggest a relatively low temperature of formation (e.g. Brey et al. 1990). The content of Al in clinopyroxene in spinel mantle-facies assemblages is defined by the reaction $\mathrm{CaMgSi}_{2} \mathrm{O}_{6}(\mathrm{cpx})+\mathrm{MgAl}_{2} \mathrm{O}_{4}(\mathrm{sp})=\mathrm{CaAl}_{2} \mathrm{Si}$ $\mathrm{O}_{6}(\mathrm{cpx})+\mathrm{Mg}_{2} \mathrm{SiO}_{4}$ (ol) (e.g. Liu and O'Neill 2004), and the low-Al spinel occurs in assemblages containing low$\mathrm{Al}$, high-Cr spinel (Pickering-Witter and Johnston 2000). This suggests that the composition of A clinopyroxene was formed under relatively low temperatures $\left(830-865{ }^{\circ} \mathrm{C}\right.$ is suggested in the Krzeniów xenoliths, see above) and in a system which was impoverished in Al. Matusiak-Małek et al. (2014) show that the A harzburgites are residues after ca. $30 \%$ melt extraction and that all clinopyroxene is a metasomatic phase. Some of the grains of this clinopyroxene preserve HREE patterns suggesting melt extraction (cf. Fig. 7), which, however, is not the case (Matusiak-Małek et al. 2014). The LREE parts of the patterns show metasomatic enrichment, associated with deep $\mathrm{Nb}-\mathrm{Ta}$ and $\mathrm{Zr}-\mathrm{Hf}$ negative anomalies, and locally, Ti anomaly (Fig. 7), which led Matusiak-Małek et al. (2014) to the conclusion that the trace element contents in the A clinopyroxene, was shaped by carbonatitic melt.
The "carbonatitic" trace element record is often obliterated to different degrees by the action of silicate melt, which is expressed by the shallowing or disappearance of the MREE "depression" of REE pattern and shallowing of negative anomalies in the trace element patterns (MatusiakMałek et al. 2014). This is connected with an increase of $\mathrm{Al}$ and decrease of $\mathrm{Ca}$ contents in the host clinopyroxene. This is best explained by chromatographic metasomatism by carbonated alkaline silicate melt, gradually enriching in carbonatitic component due to its reactive percolation in harzburgites, which eventually lead to unmixing of immiscible carbonatitic melt. Only the latter affected metasomatically distal parts of chromatographic systems, and the clinopyroxene-free A harzburgites represent pristine lithology formed by extensive melt extraction (Matusiak-Małek et al. 2014).

The "Fe-metasomatism": origin of the "B" lithology

The harzburgites of group B contain olivine whose forsterite content varies from ca. 90.0 to $84.0 \mathrm{~mol} \%$ (Fig. 4) and is positively correlated with mg\# variation in ortho- (Fig. 5) and clinopyroxene (Fig. 6). The REE patterns of clinopyroxene indicate equilibration with silicate melt (Fig. 7), as also shown by the REE patterns of orthopyroxene (Matusiak-Małek et al. 2014). Formation of group B peridotites appears to be similar to that suggested by Puziewicz et al. (2011) for the Księginki xenolith suite. The harzburgites from the Księginki SCLM were infiltrated-at mantle depth-by alkaline (nephelinitic) silicate melt which reacted with the host; the xenolith suite consists of rocks sampled at various stages of melt infiltration/reaction. The reaction of harzburgite with melt led to cryptic metasomatism which resulted in a decrease of mg\# of silicates. Similar effects of melt infiltration occur in the Krzeniów xenolith suite (Matusiak-Małek et al. 2014). The metasomatising melts were typically anhydrous, since hydrous phases (amphibole) in mantle xenoliths are scarce in the region.

Kelemen et al. (1992) showed that melts formed in mantle under high pressure are saturated only in olivine under lower pressure and will dissolve pyroxenes during reaction with peridotites. However, these melts become saturated in orthopyroxene and, when colder, in clinopyroxene, which leads to production of harzburgite or lherzolite. The highpressure phase relations of alkaline silicate melts (Baltitude and Green 1971; Tatsumi et al. 1999) show that, at pressures below $2 \mathrm{GPa}$ and in carbonate-free compositions, olivine is a liquidus phase, whereas clinopyroxene crystallises in lower temperatures; pressure decrease shifts down the temperatures of clinopyroxene crystallisation. In the complex natural systems studied by Baltitude and Green (1971), the forsterite content in olivine crystallising below 
the liquidus was down to ca. $87 \mathrm{~mol} \%$. This, together with experiments showing reaction relationships of alkaline melts with mantle peridotites (Tursack and Liang 2012 and references therein), shows that alkaline silicate melt percolation in peridotitic rock leads to decrease of $\mathrm{mg \#}$ of olivine and pyroxenes and that ortho- and clinopyroxene can be either dissolved or crystallised, depending on temperature, pressure and melt composition. In our opinion, the discussed experimental data together with observations from the Księginki and Krzeniów peridotites (Puziewicz et al. 2011; Matusiak-Małek et al. 2014) show that the "B" mantle lithology originated due to syn-volcanic percolation of alkaline silicate melts in SCLM harzburgites. We speculate that the latter might have been similar to the " $\mathrm{A}$ " lithology.

The lithology beyond standard?

SCLM below Lower Silesia and adjoining part of Upper Lusatia is dominated by harzburgites, which occur in two major varieties. The first one (group A) has highly magnesian, low aluminium characteristics with extreme depletion in $\mathrm{Zr}$ and Hf. Such rocks are unusual in the SCLM settings. Our data show that group A harzburgites escaped the metasomatic modification by alkaline silicate melts, which occurred during the Alpine rifting and volcanism. The second harzburgite variety (group B) records this metasomatism, which was generally anhydrous, did not change the low-aluminous nature of the protolith, but lowered the forsterite content in olivine to $84-90 \mathrm{~mol} \%$ and the $\mathrm{mg \#}$ of orthopyroxene to corresponding values. The harzburgites with $\mathrm{Fo}_{84-88}$ olivine are not common in SCLM (Griffin et al. 1999).

The xenoliths from the central part of the Eger Rift (České Středohoři Volcanic Complex) have mostly harzburgitic compositions, many of them contain Al-poor orthopyroxene (mg\# 90.6-92.3), coexisting in some with and Al-poor clinopyroxene of mg\# 93.1-94.7, and olivine in almost all of them contains $90.0-91.6 \%$ of forsterite (Ackerman et al. 2014). The clinopyroxene of mg\# 92.0-94.5 and extremely depleted in $\mathrm{Zr}$ and Hf occurs only in harzburgites from the Plešný Hill, which is located ca $32 \mathrm{~km}$ WSW from the Steinberg (Lusatian Volcanic Field; Ackerman et al. 2014). Thus, SCLM consisting at least partly of A harzburgites extends to this place, but probably not to the SW to central part of the Eger Rift. The data of Ackerman et al. (2013) show also that SCLM beneath SW termination of Eger Rift in north-eastern Bavaria has different lithology: it is dominated by lherzolites, ortho- and clinopyroxene are more aluminous $\left(>2.0\right.$ and $>2.7 \mathrm{wt} \% \mathrm{Al}_{2} \mathrm{O}_{3}$, respectively), and no $\mathrm{Zr}-\mathrm{Hf}$ negative anomaly occurs in clinopyroxene.

The xenoliths representing SCLM beneath located to the west Rhön Mts. in Germany and French Massif Central are predominantly lherzolites (e.g. Franz et al. 1997; Zangana et al. 1997; Lenoir et al. 2000), and those occurring in Eifel Mts. are also rich in hydrous minerals, mostly amphibole (e.g. Witt-Eickschen et al. 1993). Thus, the dominantly harzburgitic Lower Silesian-Upper Lusatian SCLM is different and "beyond standard". Since the NE part of the Bohemian Massif is located at the margin of the Variscan orogen in Europe, we speculate that the lithology of lithospheric mantle possibly is related to this palaeotectonic setting.

\section{Conclusions}

Two major lithologies occur in the SCLM beneath $\mathrm{N}$ and NE Bohemian Massif (Lower Silesia and adjoining part of Upper Lusatia), which we term "A" and "B" following the classification presented by Matusiak-Małek et al. (2014). Both of them are harzburgitic. The "A" harzburgites are characterised by highly magnesian composition of olivine (Fo $>90.5 \mathrm{~mol} \%)$ and low-Al ( $<0.10 \mathrm{apfu}$ ) orthopyroxene and are residues after extensive melting, locally only little metasomatised by carbonatite/silicate melts. The clinopyroxene in A harzburgites is all metasomatic. This lithology probably represents the lithospheric mantle accreted in Variscan times and little affected during the Alpine orogeny. The "B" harzburgites contain less magnesian olivine (Fo 90.0-84.0 mol\%) and usually preserve the Al-depleted signature of orthopyroxene. REE and trace element patterns of B clinopyroxene suggest that the protolith, which had already been affected by carbonatite metasomatism, later equilibrated with alkaline silicate melts. This lithology was shaped during the Alpine orogeny by silicate melts percolating through SCLM. The mostly harzburgitic and Al-depleted lithospheric mantle domain beneath Lower Silesia and Upper Lusatia is different from those located to the west and south-west, which are lherzolitic to harzburgitic and more aluminous.

Acknowledgments The data presented in this paper are the outcome of our studies performed thanks to projects N N307 100634 of Polish Ministry of Science and Higher Education (2008-2011) to JP and DEC-2011/03/B/ST10/06248 (2012-2015) of Polish National Centre for Scientific Research to MMM. Large part of analytical work was performed thanks to the joint 2008-2009, 2010-2011 and 20132104 projects in the frame of Austrian-Polish scientific and cultural cooperation agreement (Institute of Geological Sciences University of Wrocław and Department of Lithospheric Sciences, University of Vienna) and joint 2009-2010 project in the frame French-Polish scientific agreement POLONIUM (Institute of Geological Sciences, University of Wrocław and Midi-Pyrenees Observatory, University Paul Sabatier, Toulouse).

Open Access This article is distributed under the terms of the Creative Commons Attribution License which permits any use, distribution, and reproduction in any medium, provided the original author(s) and the source are credited. 


\section{References}

Ackerman L, Mahlen N, Jelínek E, Medaris G Jr, Ulrych J, Strnad J, Mihajlevič M (2007) Geochemistry and evolution of subcontinental lithospheric mantle in Central Europe: evidence from peridotite xenoliths of the Kozákov volcano, Czech Republic. J Petrol 48:2235-2260

Ackerman L, Špaček P, Magna T, Ulrych J, Svojtka M, Hegner E, Balogh K (2013) Alkaline and carbonatite-rich melt metasomatism and melting of subcontinental lithospheric mantle: evidence from mantle xenoliths, NE Bavaria, Bohemian Massif. J Petrol 54:2597-2633

Ackerman L, Medaris G Jr, Špaček P, Ulrych J (2014) Geochemical and petrological constraints on mantle composition of the Ohře (Eger) rift, Bohemian Massif: peridotite xenoliths from the České Středohoři Volcanic complex and northern Bohemia. Int J Earth Sci. doi:10.1007/s00531-014-1054-1

Badura J, Aleksandrowski P (2013) On the northern termination of the Eger (Ohře) Graben. In: Büchner J, Rapprich V, Tietz O (eds) Basalt 2013-Cenozoic magmatism in Central Europe, abstract \& excursion guides, pp 70-71

Baltitude RJ, Green DH (1971) Experimental study of crystal-liquid relationships at high pressures in olivine nephelinite and basanite composition. J Petrol 12:121-147

Birkenmajer K, Pécskay Z (2002) Radiometric dating of the Tertiary volcanics in Lower Silesia, Poland. I. Alkali basaltic rocks of the Opole region. Bull Pol Acad Sci Earth Sci 50:31-50

Birkenmajer K, Pécskay Z, Grabowski J, Lorenc M, Zagożdżon P (2002) Radiometric dating of the Tertiary volcanics in Lower Silesia, Poland. II. K-Ar and paleomagnetic data from Neogene basanites near Lądek Zdrój, Sudetes Mts. Ann Soc Geol Pol 72:119-129

Birkenmajer K, Pécskay Z, Grabowski J, Lorenc MW, Zagożdżon P (2004a) Radiometric dating of the Tertiary volcanics in Lower Silesia, Poland. IV. Further K-Ar and paleomagnetic data from late Oligocene to early Miocene basaltic rocks of the ForeSudetic Block. Ann Soc Geol Pol 74:1-19

Birkenmajer K, Pécskay Z, Grabowski J, Lorenc MW, Zagożdżon P (2004b) Radiometric dating of the Tertiary volcanics in Lower Silesia, Poland. III. K-Ar and paleomagnetic data from early Miocene basaltic rocks near Jawor, Fore-Sudetic Block. Ann Soc Geol Poloniae 72:241-253

Birkenmajer K, Pécskay Z, Grabowski J, Lorenc MW, Zagożdżon P (2007) Radiometric dating of the Tertiary volcanics in Lower Silesia, Poland. V. K-Ar and palaeomagnetic data from late Oligocene to early Miocene basaltic rocks of the North-Sudetic Depression. Ann Soc Geol Pol 77:1-16

Birkenmajer K, Pécskay Z, Grabowski J, Lorenc MW, Zagożdżon PP (2011) Radiometric dating of the Tertiary volcanics in Lower Silesia, Poland. VI. K-Ar and palaeomagnetic data from basaltic rocks of the West Sudety Mountains and their northern foreland. Ann Soc Geol Pol 81:115-131

Brey GP, Köhler T (1990) Geothermobarometry in four-phase lherzolites II. New thermobarometers and practical assessment of existing thermobarometers. J Petrol 31:1353-1378

Brey GP, Köhler T, Nickel KG (1990) Geothermobarometry in fourphase lherzolites I. Experimental results from 10 to $60 \mathrm{~kb}$. J Petrol 31:1313-1352

Christensen NI, Medaris LG Jr, Wang HF, Jélínek E (2001) Depth variation of seismic anisotropy and petrology in central European lithosphere: a tectonothermal synthesis from spinel lherzolite. J Geophys Res 106B1:645-664

Ćwiek M, Puziewicz J, Ntaflos T, Kukuła A (2013) Preliminary data on mantle xenoliths from the Pilchowice basanite (SW Poland). In: Büchner J, Rapprich V, Tietz O (eds) Basalt 2013-Cenozoic magmatism in Central Europe, abstract \& excursion guides, p 47
Dèzes P, Schmid SM, Ziegler PA (2004) Evolution of the European Cenozoic Rift Systems: interaction of the Alpine and Pyrenean orogens with their foreland lithosphere. Tectonophysics 389:1-33

Franz L, Seifert W, Kramer W (1997) Thermal evolution of the mantle underneath the Mid-German Crystalline Rie: evidence from mantle xenoliths from the Rhön area (Central Germany). Miner Petrol 61:1-25

Geissler WH, Kämpf H, Skácelová Z, Plomerová J, Babuška V, Kind R (2012) Lithosphere structure of the NE Bohemian Massif (Sudetes) - a teleseismic receiver function study. Tectonophysics 564-565:12-37

Grad M, Guterch A, Mazur S, Randy Keller G, Špičák A, Hrubcová P, Geissler WH (2008) Lithospheric structure of the Bohemian Massif and adjacent Variscan belt in central Europe based on profile S01 from the SUDETES 2003 experiment. J Geophys Res 113:B10304. doi:10.1029/2007JB005497

Griffin WL, O'Reilly S, Ryan CG (1999) The composition and origin of sub-continental lithospheric mantle. The Geochemical Society Special Publication 6 (Mantle petrology: field observations and high pressure experimentation: a tribute to Francis R. Joe Boyd), pp 13-45

Higgins MD (2000) Measurement of crystal size distributions. Am Mineral 85:1105-1116

Kelemen PB, Dick HJB, Quick JE (1992) Formation of harzburgite by pervasive melt/rock reaction in the upper mantle. Nature 358:635-641

Kozłowska-Koch M (1981) Petrography of ultramafic nodules in the nephelinites from Księginki near Lubań (Lower Silesia). Arch Mineral 37(1):33-59

Kukuła A, Puziewicz J, Ntaflos T, Büchner J, Tietz O (2013) Preliminary data on mantle xenoliths from Steinberg (Upper Lusatia, SE Germany). In: Büchner J, Rapprich V, Tietz O (eds) Basalt 2013Cenozoic magmatism in Central Europe, abstract \& excursion guides, pp 45-46

Lenoir X, Garrido CJ, Bodinier J-L, Dautria J-M (2000) Contrasting lithospheric mantke domains beneath the Massif Central (France) revealed by geochemistry of peridotite xenoliths. Earth Planet Sci Lett 181:359-375

Liu X, O'Neill HSTC (2004) Partial melting of spinel lherzolite in the system $\mathrm{CaO}-\mathrm{MgO}-\mathrm{Al}_{2} \mathrm{O}_{3}-\mathrm{SiO}_{2} \pm \mathrm{K}_{2} \mathrm{O}$ at 1.1.GPa. J Petrol 45:1339-1368

Lustrino M, Wilson M (2007) The circum-Mediterranean anorogenic Cenozoic igneous province. Earth Sci Rev 81:1-65

Majdański M, Grad M, Guterch A, SUDETES 2003 Working Group (2006) 2-D seismic tomographic and ray tracing modelling of the crustal structure across the Sudetes Mountains basing on SUDETES 2003 experiment data. Tectonophysics 413:249-269

Massone H-J (2006) Involvement of crustal material delamination of th lithosphere after continent-continent collision. Int Geol Rev 47:792-804

Matusiak-Małek M, Puziewicz J, Ntaflos T, Grégoire M, Downes H (2010) Metasomatic effects in the lithospheric mantle beneath the NE Bohemian Massif: a case study of Lutynia (SW Poland) peridotitic xenoliths. Lithos 117:49-60

Matusiak-Małek M, Puziewicz J, Ntaflos T (2013) Origin of intergranular aggregates in mantle xenoliths from Krzeniów basanite. Geosci Notes 1:25-49

Matusiak-Małek M, Puziewicz J, Ntaflos T, Grégoire M, Benoit M, Klügel A (2014) Two contrasting lithologies in off-rift subcontinental lithospheric mantle beneath Central Europe-the Krzeniów (SW Poland) case study. J Petrol 55 (in press)

McDonough WF, Sun S-S (1995) The composition of the Earth. Chem Geol 120:223-253 
Morimoto N (1989) Nomenclature of pyroxenes. Subcomission of new minerals and mineral names. International mineralogical association. Can Mineral 27:143-156

Napieralska M, Muszyński A (2006) Peridotite enclaves in picrobasalt from wołek Hill near Nowy Kościół (SW Poland)—preliminary data. Miner Pol Spec Pap 2:63-65

Pécskay Z, Birkenmajer K (2013) Insight into the geochronology of Cenozoic alkaline basaltic volcanic activity in Lower Silesia (SW Poland) and adjacent areas.). In: Büchner J, Rapprich V, Tietz O (eds) Basalt 2013 - Cenozoic magmatism in Central Europe, abstract \& excursion guides, pp 66-67

Pickering-Witter J, Johnston AD (2000) The effects of variable bulk composition on the melting systematics of fertile peridotite assemblages. Contrib Miner Petrol 140:190-211

Plomerová J, Vecsey L, Babuška V (2012) Mapping seismic anisotropy of the lithospheric mantle beneath the northern and eastern Bohemian Massif (central Europe). Tectonophysics 564-565:38-53

Puziewicz J, Koepke J, Grégoire M, Ntaflos T, Matusiak-Małek M (2011) Lithospheric mantle modification during Cenozoic rifting in Central Europe: evidence from the Księginki nephelinite (SW Poland) xenolith suite. J Petrol 52:2107-2145

Puziewicz J, Czechowski L, Krysiński L, Majorowicz J, MatusiakMałek M, Wróblewska M (2012) Lithosphere thermal structure at the eastern margin of the Bohemian Massif: a case petrological and geophysical study of the Niedźwiedź amphibolite massif (SW Poland). Int J Earth Sci 101:1211-1228

Sawicki L (1995) Geological map of Lower Silesia with adjacent Czech and German territories (without Quaternary deposits) 1:100000. Państwowy Instytut Geologiczny

Šibrava V, Havlíček P (1980) Radiometric age of Plio-Pleistocene volcanic rocks of the Bohemian Massif. Věstník Ústředniho Ústavu Geologickeho 55(3):129-140

Smulikowski K, Kozłowska-Koch M (1984) Basaltoids of Wilcza Góra near Złotoryja (Lower Silesia) and their enclosures. Archiwum Mineralogiczne 40(1): 53-101 (in Polish, English summary)

Tatsumi Y, Arai R, Ishizaka K (1999) The petrology of a melilite-olivine naphelinite from Hamada, SW Japan. J Petrol 40:497-509

Tietz O, Büchner J, Suhr P, Goth K (2013). Field trip 3: volcanology of the Lusatian Volcanic Field-New insights in old well known.
In: Büchner J, Rapprich V, Tietz O (eds) Basalt 2013-Cenozoic magmatism in Central Europe, abstract \& excursion guides, pp 275-297

Tursack E, Liang Y (2012) A comparative study of melt-rock reactions in the mantle: laboratory dissolution experiments and geological field observations. Contrib Miner Petrol 163:861-876

Ulrych J, Pivec E, Lang M, Balogh K, Kropáček V (1999) Cenozoic intraplate volcanic rock series of the Bohemian Massif: a review. Geolines 9:123-129

Ulrych JJ, Dostal J, Adamovič J, Jelínek E, Špaček P, Hegner E, Balogh K (2011) Recurrent Cenozoic volcanic activity in the Bohemian Massif (Czech Republic). Lithos 123:133-144

Ulrych J, Ackerman L, Balogh K, Hegner E, Jelínek E, Pécskay Z, Přichystal A, Upton BGJ, Zimák J, Foltỳnová R (2013) PlioPleistocene basanitic and melilititic series of the Bohemian Massif: $\mathrm{K}-\mathrm{Ar}$ ages, major/trace element and $\mathrm{Sr} / \mathrm{Nd}$ isotopic data. Chem Erde 73:429-450

Walter M, Katsura T, Kubo A, Shinmel T, Nishikawa O, Iyo E, Lesher C, Funakoshi K (2002) Spinel-garnet lherzolite transition in the system Cao- $\mathrm{MgO}-\mathrm{Al}_{2} \mathrm{O}_{3}-\mathrm{SiO}_{2}$ revisited: an in situ X-ray study. Geochim Cosmochim Acta 66:2109-2121

Wimmenauer W (1974) The alkaline province of Central Europe and France. In: Sørensen H (ed) The alkaline rocks. Wiley, London, pp 286-291

Witt-Eickschen G, Seck HA (1991) Solubility of $\mathrm{Ca}$ and Al in orthopyroxene from spinel peridotite: an improved version of an empirical geothermometer. Contrib Miner Petrol 106:431-439

Witt-Eickschen G, Seck HA, Reys Ch (1993) Multiple enrichment processes and their relationships in the subcrustal lithosphere beneath the Eifel (Germany). J Petrol 34:1-22

Zangana NA, Downes H, Thirlwall M, Hegner E (1997) Relationship between deformation, equilibration temperatures, REE and radiogenic isotopes in mantke xenoliths (Ray Pic, Massif Central, France): an example of plume-lithosphere interaction? Contrib Miner Petrol 127:187-203

Ziberna L, Klemme S, Nimis P (2013) Garnet and spinel in fertile and depleted mantle: insights from thermodynamic modelling. Contrib Miner Petrol 166:411-421

Ziegler PA, Dèzes P (2005) Evolution of the lithosphere in the area of the Rhine Rift System. Int J Earth Sci 94:594-614 